\title{
An Overview of the Epidemiology of Phakopsora pachyrhizi in the State of Mato Grosso, Brazil
}

\author{
Erlei Melo Reis ${ }^{1}$, Wanderlei Dias Guerra ${ }^{2}$, Mateus Zanatta ${ }^{1} \&$ Laércio Zambolim $^{3}$ \\ ${ }^{1}$ Instituto AGRIS, Passo Fundo, RS, Brazil \\ 2 Associação dos Produtores de Soja e Milho (Aprosoja), Rua Eng. Edgar Prado Arze, Centro Político \\ Administrativo, Cuiabá, MT, Brazil \\ ${ }^{3}$ Bioagro, Universidade Federal de Viçosa, Viçosa, MG, Brazil \\ Correspondence: Erlei Melo Reis, Instituto AGRIS, Rua Miguel Vargas, 291 Passo Fundo, RS, CEP 99025-380, \\ Brazil. E-mail: erleireis@upf.br
}

Received: March 22, 2021

doi:10.5539/jas.v13n6p110

\author{
Accepted: April 30, $2021 \quad$ Online Published: May 15, 2021 \\ URL: https://doi.org/10.5539/jas.v13n6p110
}

\begin{abstract}
This review seeks to expand the knowledge about the epidemiology of Asian sybean rust in the state of Mato Grosso and contribute to ensuring the economic sustainability of soybean crop. It is discussed the Phakopsora pachyrhizi potential of dispersal from Asia to South America and finally to Mato Grosso state. The origin of the Asian soybean rust inoculum within Mato Grosso is addressed by the survival in volunteer and soybean weed plants (Pitelli, 2015) in other crops such as cotton. Data on the adverse environmental effect on the soybean plants survival are shown mainly the water deficit from June to August. Reports on the effect air temperature and mainly solar radiation on the mortality of airborne spores during their anemophilous spread on sunny days are also discussed. This increase of knowledge aims to make the soybean-free period more efficient by the knowledge on the soybean plants survival and on the fungus viability in the month of August. Due to the proximity of soybean farms, during the soybean-free period, in other states (Tocantins, Goiás, Rondônia, etc.) and in other neighbor countries we discuss the likelihood that inoculum in the state may also originate in out-of-state crops during the Mato Grosso soybean-free period.
\end{abstract}

Keywords: Asian soybean rust, Glycine max, soybean-free period, sowing time regulation, winter fallow

\section{Introduction}

In Brazil, soybean [Glycine max (L.) Merr.] is grown from Rio Grande do Sul to the north in Amapá state and from the west in Rondônia to the east in Maranhão state extending the growing season and the period of green plants presence in the field.

The soybean grown area in Mato Grosso in the 2020/21 season was 9.951 million ha IMEA (2019).

The fast dispersion of Phakopsora pachyrhizi (H. Sydow \& P. Sydow, 1914), causal agent of Asian soybean rust (ASR) is unique; first noted in Japan in 1902, then in Australia (1960), Africa (1998), South America (2001), the United States (2004) and Canada (2007) (Caldwell et al., 2015; Morel, 2001; Rogers \& Redding, 2004; Rossi, 2003). Therefore, by 2007 fungal pathogen is present in all places where soybean is grown in the world and in Mato Grosso.

Another important aspect of ASR is the high caused damage (Nutter et al., 1993) which can be appraised in soybean fields by the mathematical functions developed by Danelli et al. (2015).

\section{Basic Concepts}

Volunteer plant: Volunteer plant is one that originates from grain voluntarily germinated anywhere that has not been sown.

Soybean weed: The word weed is used to designate any superior plant that interferes with the interests of man and the environment (Pitelli, 2015).

Green-bridge: Green-bridge is the term applied to volunteer soybean plants, cultivated soybean and soybean weeds, where $P$. pachyrhizi inoculum is sustained between soybean seasons. 
Winter fallow: Winter fallow is defined as a cultivated farm left to its own natural growth and not planted with seeds; or leaving the land either uncropped and weed-free or with only volunteer vegetation during at least one period when a crop would traditionally be grown (Haas et al., 1974). In Mato Grosso state the annual cycle plants development is controlled by drought during winter season. Thus, the natural fallow in MT is the period extended from June to September.

Soybean free-period (SFP): Soybean free-period is the 92 days period imposed by law (June $15^{\text {th }}$ to September $15^{\text {th }}$ ) without the soybean cultivation or volunteer plants in the field. The SFP was stated by Joint Normative Instruction No. 001/2021, between the Economic Development Secretariat and the Mato Grosso State Agricultural Defense Institute (INDEA-MT). This legislation does not accepts that the soybean plants survive in farms under winter fallow from June $15^{\text {th }}$ to September $15^{\text {th }}$, except for research. The majority of the volunteer soybean plants and soybean weed that emerged after harvesting in January and February and that survive green infected by rust should have in same conditions 100 to 210 days cycle to reach still green September $15^{\text {th }}$ or as volunteer plants up to July as soybean weed. Therefore, during the winter fallow they have to survive until the presence of green leaves of the new crop to ensure the annually fungus survival in the state. The soybean cycle does not last that long! The emergence of new voluntary seedlings after harvesting in March/April would require a 140 a 150 days cycle to reach September $15^{\text {th }}$ and would face greater drought adversity, which is practically impossible in fallow situations, but possible in the urban areas where they do receive artificial light and water from other sources than rain.

\section{The Climate in Mato Grosso}

The predominant climate in the State of Mato Grosso is the tropical with dry winter, according to the Köppen classification. This climate is characterized by a rainy season in summer, from November to April, and a clear dry season in winter, from May to September (July is the driest month). The mean temperature of the coldest month is above $18^{\circ} \mathrm{C}$, and the rainfall is above $750 \mathrm{~mm}$ per year, reaching $1800 \mathrm{~mm}$ (EMBRAPA, 2020).

\section{Soybeans Grown Under Irrigation}

The winter fallow starts in May/June when begins the dry season lasting to September. This period is extremely dry to grow annual crops without irrigation leading the growers to cultivate soybean under irrigation.

Irrigated crop began in the 2002/03 season and continued until 2005/06 when the state banned soybean grown under irrigation. Such fields were sown in April-June, beginning the dry period between season, and harvested in August-September. Sprinkler irrigation by center pivot fulfilled the water requirements for soybean development as well for the duration of the daily leaf wetness period necessary for uredosporos germination, penetration into the leaves, establishment of parasitism and sporulation (Marchetti et al., 1976; Melching et al., 1989).

The soybean acreage under sprinkler irrigation reached about 16,000 ha and received directly the inoculum from the last green rainfed fields harvested in February considered a cultivated green bridge. Under this situation disease intensity was so high that growers sprayed fungicides up to five times and even so, some fields were abandoned due to control failure (Seixas \& Godoy, 2007)

\section{The Span of Time Between Two Soybean Seasons and the Fungus Survival}

The time elapsed between the last rainfed soybeans crop and the presence of next irrigated green soybeans determines whether or not the need for green bridges for inoculum survival. If the environment is adverse to the inoculum survival (low RH, high temperature and solar radiation) and the time between the two seasons (rainfed and irrigated) is long, the green bridges presence is required to keep the fungus viable through its generations on the volunteer plants. On the other hand, if there is no long time between green soybeans (end of rainfed and beginning of irrigated), other kind of green bridge is not necessary. The inoculum dynamics would be similar to two seeding times within the same season or soybean succeeded by soybean without span of time between them.

Therefore, similar to green bridges the cultivated irrigated areas maintained the host and multiplied the fungus between rainfed soybean crop from April to September, totaling six months.

After harvesting irrigated soybean two situations could occur:

(a) Irrigated crop near in time to rainfed crop for the next season. From the last irrigated crops still green and infected the inoculum may be disseminated from irrigated to rainfed crop without the need for green bridges. A short time for spores not to lose viability.

(b) Harvesting irrigated crop and rainfed crop emerging distant in time and requiring green bridges. Due to the long time between irrigated and rainfed crops the presence of green bridges, would be required after harvesting irrigated soybean until September $15^{\text {th }}$. 
In one way or another, the pathogen was dispersed from the new areas sown next year continuing the disease annual cycle.

\section{The Soybean Free-Period}

Early on, the researchers visualized the threatening situation of irrigated soybeans and created the SFP in 2006 season primarily in Mato Grosso state with the aim to avoid irrigated soybean cultivation seeded in February/March.

The SFP coincides with the winter fallow imposed by the dry, hot environment with high solar radiation. Its objective is to eliminate or reduce the soybean plants population in between seasons, reduce the fungus survival period and, therefore, the inoculum amount due to the absence of the host and thus delay the disease onset in the next rainfed crop (Seixas \& Godoy, 2007). Therefore, SFP is imposed by law and winter fallow by the nature! Was SFP more efficient in eliminating volunteer soybean plants or winter fallow?

It has been reported the ban impact of irrigated crop cultivation resulted in a delay in the occurrence of rust in rainfed crop (Seixas \& Godoy, 2007).

The legislation was improved to include the elimination of volunteer plants, but without data confirming their presence on September $15^{\text {th }}$ (Guerra et al., 2010).

\section{Volunteer Soybean Plants and Rust Green Bridge}

If the span of time is short between harvesting infected irrigated soybean fields and the establishment of the new rainfed crop (starting on September $15^{\text {th? }}$ ) there would be no need for green bridges. Under this situation how long the spores need to survive out of the host?

However, the presence of rainfed-infected green soybeans and irrigated soybeans with new green leaves should overlap at the same time. At the end of the rainfed season time, before SFP, new plantings were restarted in January and February, which were amended with new irrigated plantings from May/June. A literal green bridge was created from the rain fed areas of the previous season, passing through the late seedongs and the irrigated areas of the middle of the year until the new harvest. In other words, at the end of the cycle, the infected rainfed crop works as a source of inoculum for the irrigated areas as well fort the next season. Irrigated soybeans played the role of green bridges between the rainfed from one seanson to the next.

On the other hand, when the irrigated soybean cultivation was prohibited, during the SFP, there was an increase in time between the last infected green field (January/April harvest) and the first rainfed crop without green soybeans, September $15^{\text {th }}$. It is like that the spores would not survive on their own without the host, thus they now need the presence of green soybean plants to ensure their viability at that time. The time between green rainfed soybeans and green leaves (infection sites) of the new rainfed season is, in the absence of irrigated soybeans, very long (92 days in MT state) with the inoculum density and viability reduced or eliminated. Therefore, during the SFP the fungus needs to survive and multiply only through the green-bridges colonization. But let us question, is there scientific evidence on the presence of infected volunteer plants on winter fallow farms on September $15^{\text {th }}$ ?

\section{The Environment During the Soybean Free-Period or During Winter Fallow}

During the 92 days of SFP the environment is unfavorable for both the plant development (Farias et al., 2007) and for the fungus survival (Patil et al., 1998; Godoy \& Flausino, 2004; Isard et al., 2006; Nicolini et al., 2010).

\section{Water Requirement of Soybean}

The water requirement for soybean to obtain maximum yield ranges from 450 to $800 \mathrm{~mm}$ per crop cycle depending on environmental conditions and crop management (FAO, 1986; Farias et al., 2007). It is essential to identify the regions of MT state where soybean can survive in winter fallow farms due to the rain deficit, growing and infected by rust, especially at the end of the dry period (September $15^{\text {th }}$ ). The presence of such source of inoculum must be quantified not only in the urban perimeters of cities, but mainly in cultivated areas as soybean weed, in authorized exceptional crops during the SFP and also in soybean fields under winter fallow during the dry period.

In the urban areas of some cities such as Sapezal, Campo Verde, Primavera do Leste and Campo Novo do Parecis, volunteer soybean plants have been found with old rust black lesions and uredia around the whole year. These plants received sewage supplementation and under public lighting increase their cycle and leaves becoming leathery. Anyhow it is necessary further studies to determine its importance as inoculum source. In compliance with the SFP such plants should be eliminated as soon as they emerge. 
To understand the situation we should compare the minimum water demand for soybeans of $450 \mathrm{~mm}$, with the rainfall from May to August with $43.9 \mathrm{~mm}$ in 120 days (INMET, 2019) .

Under this deficit, soybean plant development on farms in MT during the SFP, or winter fallow farms, hardly occurs, which must be confirmed in surveys directed at the search for infected voluntary plants present in farms. If soybeans do not survive this water deficit, and rust still occurs in the next season, other inoculum source must be considered. If this source of inoculum inside the state does not occur in an enough 'population' to start the epidemic in the next season, the hypothesis is that the inoculum may originate outside the state, specially in irrigated areas during the SFP.

\section{Water Stimulus and the Fungus Infectious Process}

The environment is hostile in the SFP preventing the soybean plant development, whose presence is required for the survival and multiplication of P. pachyrhizi. And in relation to the spores deposited on leaves, natural stimulus for spore germination is water that determines a mandatory and irreversible response (Reis \& Wordell, 2004). In P. pachyrhizi, the infectious process requires $>8$ hours a day of continuous leaf wetness (Marcheti et al., 1976; Melching et al., 1989), being the temperature not limiting for the process (Blum et al., 2015). Without the presence of liquid water required for spore germination, infection does not occur. The intensity of the rust epidemic is proportional to the frequency of infection-critical periods occurring in the soybean cycle (Reis \& Wordell, 2004). However, even if there were survived voluntary soybeans from June $15^{\text {th }}$ to September $15^{\text {th }}$, due to the water deficit, the rain frequency should not be enough to satisfy the leaves daily wetting duration and therefore no opportunity for infection. This can be proven with dripping irrigated plots without leaf wetness during the SFP.

One hypothesis is that the SFP consisted mainly of a ban on the cultivation of irrigated soybeans (from June to September $15^{\text {th }}$ ). Therefore, the soybean elimination consisted of removing the irrigation water which eliminates the host in the state during winter fallow.

If there are no soybean plants after the harvest of rain fed: (a) volunteer soybeans in significant density and (b) neither water to ensure the infectious process it is likely that there would be no need for legislation on the SFP as nature alone eliminates volunteers and the fungus between seasons. Therefore, was SFP imposed by law, or due to winter fallow by the nature?

\section{Temperature and Soybean Plant Development}

Soybean has been better adapted to regions where temperatures fluctuate between $20^{\circ} \mathrm{C}$ and $30{ }^{\circ} \mathrm{C}$ and the ideal temperature for its development is around $30^{\circ} \mathrm{C}$ (FAO, 1986).

\section{Temperature and Uredospores Germination}

The thermal requirements for P. pachyrhizi spores germination were studied in detail by Blum et al. (2015). The lower thermal threshold was $4{ }^{\circ} \mathrm{C}$, the upper $34{ }^{\circ} \mathrm{C}$, and the optimal temperature for maximum germination 22.2 ${ }^{\circ} \mathrm{C}$ (Figure 1).

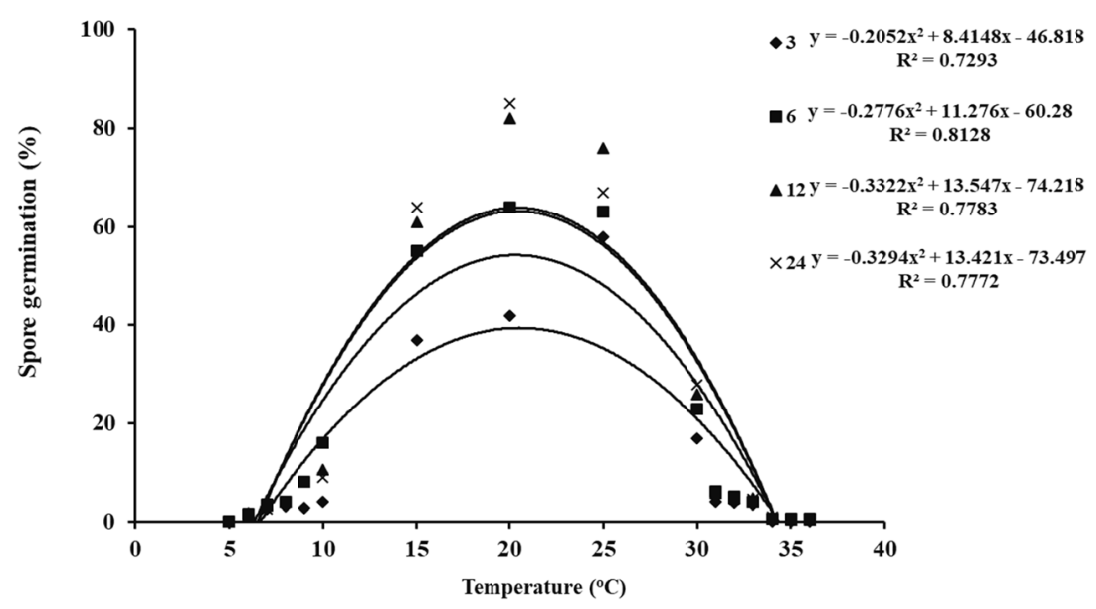

Figure 1. Effect of four exposure times, 3, 6, 12, and $24 \mathrm{~h}$, under different temperatures on Phakopsora pachyrhizi uredospores germination plated on soybean leaf extract agar substrate under dark (Blum et al., 2015) 


\section{Temperature and Spores Viability}

In addition to the water deficit that prevents soybean survival in the dry period the effect of temperature on the uredospores mortality exposed to different temperatures in detached leaves was quantified by Twizeyimana and Hartman (2010). The spores were killed in four days at 40 to $50{ }^{\circ} \mathrm{C}$, in eight days at $30{ }^{\circ} \mathrm{C}$ and in 18 days at $25{ }^{\circ} \mathrm{C}$ (Figure 2).

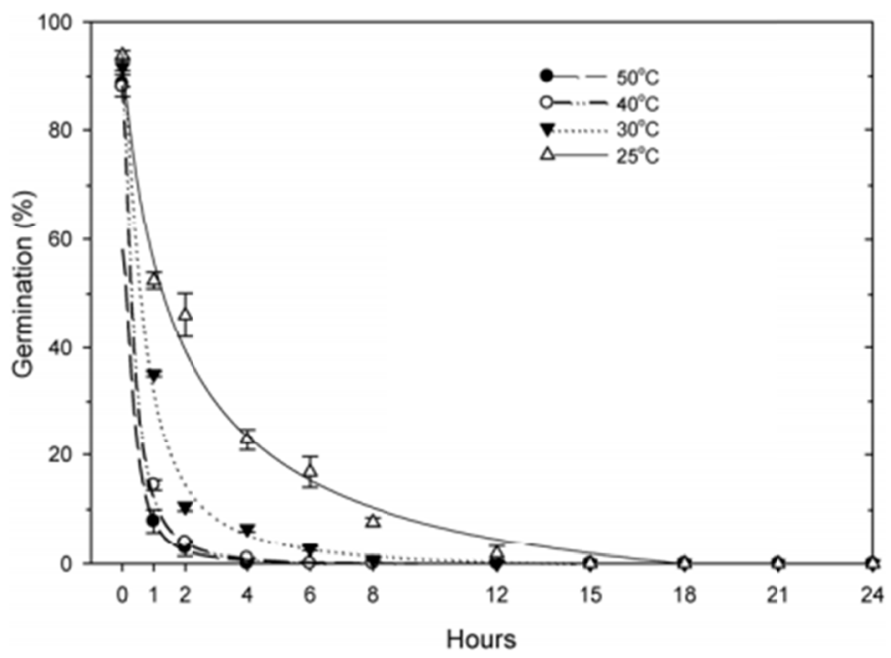

Figure 2. Viability of Phakopsora pachyrhizi uredospores on detached soybean leaflets exposed to four different temperatures (Twizeyimana \& Hartman, 2010)

In this report at $25{ }^{\circ} \mathrm{C}$ the spores lost viability in 18 days. In another study, Godoy and Flausino (2004) showed that the uredospores remained viable for 17 days in the laboratory bench environment, for 60 days in a refrigerator and for 30 days (720 hours) in detached leaflet. Patil et al. (1998), in India, reported the viability of spores for 55 days in detached, stacked leaves, and protected by the shade of a tree. These reports reinforce the hypothesis that both soybean and the fungus would hardly survive during the 92 days of water deficit durinig the winter fallow.

\section{Temperature and the Infectious Process}

An important finding was reported by Danelli et al. (2015) regarding soybean infection by P. pachyrhizi. The authors showed that soybean infection by $P$. pachyrhizi does not occur at temperatures $\geq 30{ }^{\circ} \mathrm{C}$, confirming the Marchetti et al. (1976) report that in plants incubated at $27.5^{\circ} \mathrm{C}$ did not show infection regardless of the wetting period length.

Therefore, the adversity of the environment in MT, from June $15^{\text {th }}$ to September $15^{\text {th }}$ for 92 days, has the potential to eliminate the inoculum and prevent infection.

\section{Solar Radiation and Uredospores Viability}

In addition to the direct effect of temperature on spore viability another factor of its lethality is solar irradiation. When present in the air during uredospore anemophilous spread are sensitive to solar radiation (Isard et al., 2005; Isard et al., 2006; Nicolini et al., 2010). The monthly global daily radiation ( $\left.\mathrm{MJ} \mathrm{m}^{-2} \mathrm{day}^{-1}\right)$ mean in the Amazon region of Mato Grosso were reported by Souza et al. (2016). Depending on the exposure time it has the potential to kill the spores exposed to this radiation dose.

Regarding the effect of radiation on the viability of the fungus in a study conducted in Rio Grande do Sul state, $P$. pachyrhizi uredospores kept in open empty plastic petri dishes, and exposed directly to solar radiation were killed in five hours (Nicolini et al., 2010) (Figure 3). 


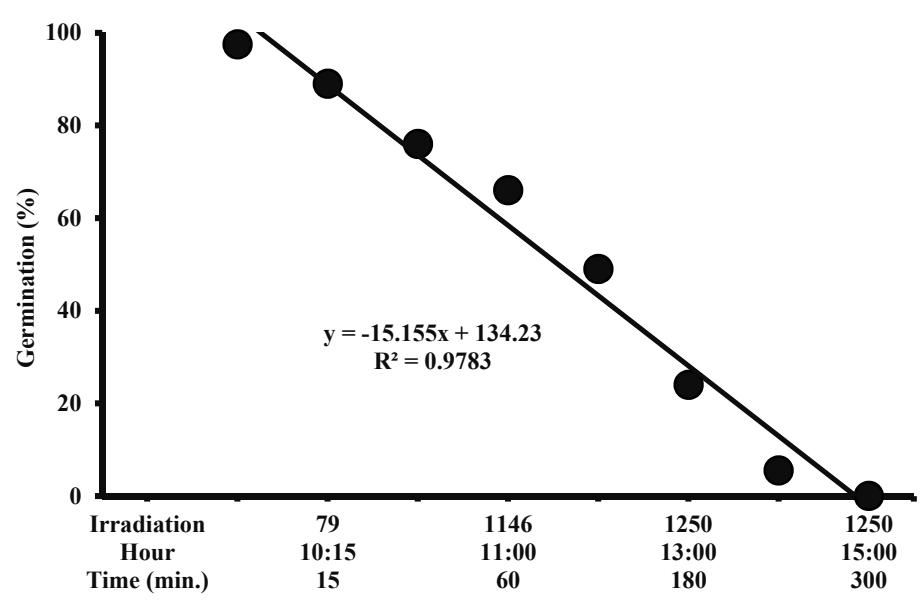

Figure 3. Viability of Phakopsora pachyrhizi uredospores on a dry surface directly exposed to solar irradiation

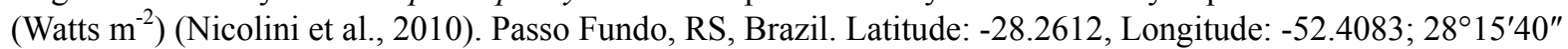
South, $52^{\circ} 24^{\prime} 30^{\prime \prime}$ West

However, Isard et al. (2006) reported that radiation only reaches the lethality value on sunny days. The maximum potential lethality occurs precisely during the soybean free-period.

Considering the environmental adversities (June $15^{\text {th }}$ to September $15^{\text {th }}$ ) for soybeans and P. pachyrhizi, data that prove the presence of infected volunteer plants under winter fallow farms on September $15^{\text {th }}$ should be generated and published as a priority.

\section{Survival of Phakopsora pachyrhizi}

The presence of teliospores, dormancy or resting spores, has been described in P. pachyrhizi and its germination in the laboratory has been shown. However, the formation of telial sori is rare in most hosts in tropical regions, as favorable conditions, such as humidity and temperature between $10{ }^{\circ} \mathrm{C}$ and $20^{\circ} \mathrm{C}$ at night, do not occur to induce the production of telial sori (Souza et al., 2016). Teliospores has not been found in Brazil, but have been reported in Argentina, and what is the most important, no intermediary host has been found yet. Thus, two survivals mechanisms should be considered: in the parasitic phase exploring the host and sporulating, and as uredospores out the host during the airborne spread, or sedimented on other surfaces than soybeans.

The SFP explores the P. pachyrhizi survival requirement exclusively through the parasitism of voluntary soybean plants. Therefore, the principle of rust control in the SFP consists of eliminating the fungus chance of survival, so it is eliminated by the absence of the soybean plant. Has the SFP after the ban on irrigated cultivation been efficient in eliminating P. pachyrhizi spores, mainly in August $15^{\text {th }}$ to September $15^{\text {th }}$, the period that precedes the new cultivation season? One hypothesis that must be confirmed is related to the reduction or elimination of the inoculum from on September $15^{\text {th }}$, whether or not due exclusively to the SFP determined by the legislation or naturally due to the water deficit, high temperatures and lethal solar irradiation.

Data from the evaluation of the SFP efficiency after the ban of irrigated soybeans would be of great importance. The detection of rust with $<5 \%$ of foliolar incidence in commercial crops before and during the duration of the free-period comparing the presence of the initial inoculum in these two moments, would be the main scientific tool to prove the effectiveness of the SFP in the state after the ban on irrigated crops (Reis et al., 2020).

\section{Host Range of Phakopsora pachyrhizi}

Another possibility for P. pachyrhizi survival during the SFP is the parasitism of alternative hosts. The occurrence of these hosts can implicate the efficacy of the SFP. There was no record found on P. pachyrhizi host range in Mato Grosso. The P. pachyrhizi fungus has a wide host range (Slaminko et al., 2008) all from the Fabacea (Leguminosae) family. In Brazil, kudzu (Pueraria lobata (Willd.) Ohwi), perennial soybeans (Neonotonia wightii (Wight \& Arn.) Lackey) and common beans (Phaseolus vulgaris L.) have been reported as host with proof of pathogenicity (Reis, 2019; Jaccoud Filho et al., 2007).

In order to understand the survival of $P$. pachyrhizi in Mato Grosso and how to explore it in the inoculum reduction would be useful to have record of susceptible host plants vegetating in MT mainly from June/September $15^{\text {th }}$. Annual or semiannual cycle plants hardly survive the harsh environment so a survey of 
alternative hosts should focus on perennial species of the Fabacea family in the vicinity of soybean fields. It must be reinforced that no annual cycle plant can survive winter fallow in MT.

\section{Inoculum Source Within the State}

\subsection{Volunteer Plants}

The presence of these plants is due to the grain loss during harvest, transportation along roads, highways, around warehouses, etc. Such plants are of great importance for the survival and maintenance of the $P$. pachyrhizi inoculum during the inter-season time (Guerra et al., 2010). It is reinforced that its presence must be verified/quantified mainly at the end of the SFP on September $15^{\text {th }}$. In their absence due to the unfavorable environment the inoculum is also absent in farms or regions.

Volunteer plants serving as a source of inoculum, or not, are present in a high population, soon after harvesting commercial crops from January onwards when there is enough water for grain germination and plant development. However, they are not epidemiologically important at this time. On the contrary, they are determinant to the occurrence of the disease when present and infected by P. pachyrhizi at the end of the free-period, September $15^{\text {th }}$ onwards and after the plant establishment of the next season.

\subsection{Soybean Weed Plants}

It should be added to the volunteer plants the presence, population and period of inoculum maintenance and multiplication, the soybean weed (Pitelli, 2015). Its presence in cotton fields, areas with brachiaria, crotalaria, beans, sesame, sunflower, corn, and etc. should also be annually monitored. Would soybean weed plants survive during the winter fallow period?

According to data from IMEA-MT (2019), the area sown with cotton in the state in the 2018/2019 normal season without soybeans has been predecessor crop, was 158,932 ha. However, the second cotton crop, carried out immediately after the soybean harvest, which begins in January, was 913,544 ha. In these crops there are soybean weed plants infected by rust especially in the January sown cotton. In randomly sampled fields the population of soybean weed plants in cotton reached 53,000/ha, beans 84,000/ha and corn 35,000/ha (unpublished data). In view of the importance of soybean weed in cotton crop, bean and other crops, they deserve to be quantified in detail analyzed and mapped to estimate their role as $P$. pachyrhizi primary inoculum source.

Soybean weeds infected by ASR may also be contributing to a greater degree to reduce the efficacy of site-specific fungicides in MT. These cotton fields receive between 6 to 16 fungicide sprays during the plant cycle usually with the same active ingredients (site-specific) used to control rust in soybean crop. The evolution of the reduction in the sensitivity of P. pachyrhizi to site-specific fungicides should be aggravated under this situation. We may infer that the complete elimination of soybean weeds is more important than the time of soybean sowing in Mato Grosso state. The application of herbicides, especially in cotton crop, has not been sufficient for the complete elimination of these voluntary soybean plants. On the contrary, in some cases the herbicide serves as a kind of chemical pruning, extending the soybean weed cycle into the SFP.

As an aggravation of the situation it should be mentioned that the fungus Corynespora cassiicola (Berk. \& MA Curtis) Wei, the causal agent of the target spot both in cotton and soybeans, already has a mutation that confers resistance to SDHIs fungicides (Stefano Torriani, Syngenta, UK, July, 2020).

Therefore, more important than being green bridges soybean weed plants receive the same site-specific fungicides which should result in a greater directional selection resulting in the P. pachyrhizi sensitivity reduction to these fungicides season after season (Reis et al., 2015).

\section{Inoculum Source Out of the State}

\subsection{Soybean Grown in Brazil}

In the north of the equator line in Amapá state in the 2018/19 season 20,000 ha were grown and in Roraima 40,000 ha sown from April to May and harvested in August to September, therefore during the free-period in southern region (Dr. Amélio Dalagnoll, personal information, Embrapa Soja, August, 2020). In Tocantins state, in the tropical lowlands in the same period 60,000 ha cultivated area rust was detected in September, 2019 growing season. In Goiás state, 3,000 ha has been annually cultivated and ASR detected in Sptember 2020.

\subsection{Soybean Cultivated in Other South American Countries}

In Bolivia, soybean is sown from June $5^{\text {th }}$ to July $15^{\text {th }}$ in an area of 300 thousand hectares (Eng. Juan Sauto Mendez, personal information, UPL, Bolivia, August, 2020) with the potential to also compromise the SFP 
efficacy in Mato Grosso. In Paraguay, 600,000 ha are cultivated in the same period (Eng. Fabrizio Micheletto, personal information, UPL, Paraguay, August, 2020) and in Ecuador the cultivated area was 21,051.00 ha in 2018/19, sowing in May and June (Prof. Dr. Felipe Rafael Garces Fiallos, personal information, Universidad Quevedo, Ecuador, September 2020).

\subsection{Colombia, Venezuela, and Guyana}

In these countries the soybean cultivation area continues to grow with the potential to provide inoculum to the Midwest region of Brazil, regardless of distance. The spread of spores by atmospheric circulation is not limited by the countries and states borders where Mato Grosso is surrounded by commercial soybean crop.

\section{Transport Distance of Phakopsora pachyrhizi Uredospores}

The spread distance from the identified primary inoculum sources is not a limiting factor to the occurrence of rust in the state.

According to Christiano and Scherm (2007), in the United States, the anemophilous dispersion of the $P$. pachyrhizi uredospores occurred at an average rate of 8.8 and $10.4 \mathrm{~km} /$ day in the 2005 and 2006 seasons, respectively, and based on this information, and considering the duration of the epidemic in Passo Fundo, RS, in the 2018/19 season, of 30 days (from the day when the foliolar incidence reached $100 \%$ until the defoliation evaluation), the spores can be transported in 10 days to $302 \mathrm{~km}$ from a single inoculum source.

The distance between farther west farms in MT (Comodoro and Campos de Júlio counties) from farther east farms in Bolivia (San Pedro county) is nearly $400 \mathrm{~km}$. The distance between commercial fields in Mato Grosso and those grown in tropical lowlands in Tocantins state is about $150 \mathrm{~km}$. Asian rust occurs causing damage in both or in all situations.

The fungus spores are classified as dry, sensu Maude (1996), light, small (15-24 × 18-34 $\mu \mathrm{m})$ (Hartman et al., 2015), spread by wind, can be present in the air at all moments and in all places, which may explain the inoculum arrival to the American continent as mentioned by Caldwell and Laing (2002). However, parasitism occurs under favorable environment conditions ( $>8 \mathrm{~h}$ continuous leaf wetness and temperature $20-25^{\circ} \mathrm{C}$ ) (Blum et al., 2015; Melching et al., 1989).

Considering the distance and speed of the inoculum spread registered in the American continent the rust was recorded for the first time in Paraguay, in 2001 (Morel, 2001); later in Rio Grande do Sul (Reis, Casa, \& Michel, 2001/2), Argentina in 2001/2 (Rossi et al., 2003), Bolivia and Uruguay in 2002; Colombia in August 2004 and in the United States in November 2004 (Roger \& Redding, 2004). Therefore, moving a long distance in three years from Paraguay to the south of the United States.

However, Isard et al. $(2005,2006)$ and Nicolini et al. (2010) reported that uredospores are sensitive to solar radiation, inactivating them within up to five hours of direct exposure. Isard et al. (2005) added that the elimination by irradiation does not prevent the introduction of the pathogen in distant areas, since the viability of the spores is ensured by their transport in periods with a sky covered by clouds and absence of lethal radiation. In Mato Grosso, this favorable condition occurs just during the soybean growing period and not in the SFP.

A view of soybean panorama cultivation in South America, in regions without a harsh winter, as in Argentina, allows a better understanding of $P$. pachyrhizi inoculum dynamics (Table 1). 
Table 1. Months of commercial soybean cultivation in Brazilian states and South American countries overlapping the soybean free-period (winter fallow) in Mato Grosso State

\begin{tabular}{|c|c|c|c|c|c|c|c|c|c|c|c|c|}
\hline \multirow{2}{*}{ Country/state } & \multicolumn{12}{|c|}{ Months } \\
\hline & Jan & Feb & Mar & Apr & May & Jun & Jul & Aug & Sep & Oct & Nov & Dec \\
\hline \multicolumn{13}{|l|}{ Brazil } \\
\hline \multicolumn{13}{|l|}{ Amapá } \\
\hline \multicolumn{13}{|l|}{ Maranhão 1} \\
\hline \multicolumn{13}{|l|}{ Maranhão 2} \\
\hline \multicolumn{13}{|l|}{ Mato Grosso } \\
\hline \multicolumn{13}{|l|}{ M. G. Sul } \\
\hline \multicolumn{13}{|l|}{ Pará Sul } \\
\hline \multicolumn{13}{|l|}{ P. Paragominas } \\
\hline \multicolumn{13}{|l|}{ P. Santarém } \\
\hline \multicolumn{13}{|l|}{ Piauí } \\
\hline \multicolumn{13}{|l|}{ Santa Catarina } \\
\hline \multicolumn{13}{|l|}{$\begin{array}{l}\text { Sergipe/Alagoas/ } \\
\text { Bahia }\end{array}$} \\
\hline \multicolumn{13}{|l|}{ Rondônia } \\
\hline \multicolumn{13}{|l|}{ Roraima } \\
\hline \multicolumn{13}{|l|}{ Tocantins } \\
\hline \multicolumn{13}{|l|}{ Goiás } \\
\hline \multicolumn{13}{|l|}{ Other countries } \\
\hline \multicolumn{13}{|l|}{ Bolivia } \\
\hline Paraguay & & & & & & & & & & & & \\
\hline
\end{tabular}

Note. $\square$ Period of soybean cultivation;

Winter fallow;

Soybean free-period in Mato Grosso State. However, soybean can be cultivated in this period for research purposes, or for commertial seed production (Tocantins and Goiás).

Therefore, if soybeans are grown throughout the year somewhere in Brazil or in South America ASR must also be present.

The effective inoculum of $P$. pachyrhizi deposited in soybean crop as on September $15^{\text {th }}$, may be originated within the state or come from other external sources as discussed (Table 1). As the environment from June $15^{\text {th }}$ to September $15^{\text {th }}$ is adverse to soybeans it can be inferred that the inoculum from the state external sources should not be underestimated.

In this sense, after the SFP, the state may be receiving the inoculum from the other sources mentioned, which can be proved with the use of trap-soybean plant plots.

Finally, it can be inferred that from the mentioned sources of inoculum, inside or outside the state, the annual occurrence of soybean rust in MT, is ensured.

In view of the discussion to improve the SFP, and maintain the sustainability of soybean it is suggested:

(i) Intensify inspection on the efficient elimination of volunteer soybean plants if present in August;

(ii) Develop efficient herbicide management technology to eliminate soybean weeds avoiding receiving site-specific fungicide sprayings;

(iii) Prevent the cultivation of soybean sown in December, replacing by February in order to reduce the damage caused by rust and the directional selection pressure of site-specific fungicides on P. pachyrhizi (Reis et al., 2020);

(iv) Annually monitor in regions strategically located in Mato Grosso the time of rust onset in commercial fields with $<5 \%$ leaflet incidence; 
(v) Apply site-specific fungicide always mixed with multisite which results in the highest profit, after the rust detection, in the whole area and in all sprayings (EMBRAPA, 2010; Reis et al., 2018).

\section{Soybeans Seeding Time and Reduced Number of Fungicide Sprayings}

Standardizing the sowing period is not the most appropriate strategy to make chemical control of soybean rust more efficient. Normative Instruction 001/21 (INDEA, 2021) deals with the regulation of soybean sowing date in order to reduce the number of fungicide sprayings and so to reduce the directional selection of the fungus to site-specific fungicides.

\section{Asian Soybean Rust Escape}

Disease escape occurs when susceptible soybean plants do not become infected by ASR for some reason. This may be due to some anatomical or physical character or environmental, in which conditions are not conducive to disease development. Disease escape may be exampled for February sown soybean that faces a less prone environment for infection such those sown mainly in the other months such as December (Reis et al., 2020a, 2020b).

\section{Final Remarks}

The objective of plant disease management with fungicide is to reduce or avoid the damage caused by the disease. The damage is not related to the disease presence but to its intensity (Reis et al., 2018).

Some empirical practices widely used by producers in the state of Mato Grosso lead to an increase in the number of fungicide applications in soybean crops such as:

(1) Sprayings at vegetative stages without taking into account the presence and damage caused by ASR (Reis et al., 2018, 2019);

(2) Spraying performed in the phenological stage R1 without considering the presence of rust and the damage caused by the disease (Reis et al., 2018, 2019);

(3) Preventive application, although all mobile penetrating fungicides have preventive, curative and eradicative action (Godoy \& Canteri, 2004; Reis \& Zanatta, 2016);

(4) Application in the pre-closing soybean crop rows without considering the presence and the damage resulting from the rust intensity (Reis et al., 2018, 2019);

(5) Spraying site-specific fungicides (DMIs, QoIs, SDHIs) in double or triple mixtures without adding multisites with less than $40 \%$ efficacy. The lower efficiency demands a greater number of applications;

(6) Spraying chemicals without proven fungicidal efficacy and not recommended;

(7) Avoid December sown soybeans with a greater rust severity (Reis et al, 2020a, 2020b);

(8) Spraying soybeans weeds infected by rust with the same active ingredients worsening the evolution of reduced sensitivity and the development of fungus resistance to site-specific fungicides.

Conversely, the use of scientifically proven practices results in the rational use of fungicides such as:

(i) Concentrate soybean sowing in September, October, November and February;

(ii) Avoid sowing in December;

(iii) Start applications before the incidence of rust reaches the economic damage threshold, that is, with $<5 \%$ of foliolar incidence (IF) (Reis et al., 2018);

(iv) Always apply fungicide containing site-specific (DMI or QoI) plus multisite (chlorothalonil, or mancozebe, or copper oxychloride) throughout the cultivated area and in all sprayings (Reis et al., 2017);

(v) Apply fungicies with proven efficacy ( $>70 \%$ ) ensuring the greatest economic return;

(vi) Avoid soybean weed plants that result in the highest pressure of directional selection.

Finally considering:

- Mato Grosso leadership in Brazilian soybean production with a cultivated area of 9,699 million hectares in 2018/19 season (IMEA-MT, 2019);

- Annual damage caused byASR (Danelli et al., 2015);

- The main control measure based on the use of fungicides with an increase in production cost; 
- The evolution of the reduction in the fungus fungicide sensitivity to site-specific fungicides season after season (Reis et al., 2015);

- The limited use of multisite fungicides the main weapon to fight against resistance.

\section{References}

Blum, M. M. C., Reis, E. M., Francieli, T. V., \& Carlini, R. (2015). In vitro effect of substrate, temperature and photoperiod on Phakopsora pachyrhizi urediniospore germination and germ tube growth. Summa Phytopathologica, 41(2), 101-106. https://doi.org/10.1590/0100-5405/1999

Caldwell, P., \& Laing, M. (2002). Soybean rust-A new disease on the move. Plant Disease, 89, 109.

Christiano, R., \& Sherm, H. (2007). Quantitative aspects of the spread the Asian soybean rust in the southern United States, 2005 to 2006. Phytopathology, 97, 428-1433. https://doi.org/10.1094/PHYTO-97-11-1428

Danelli, A. L. D., Reis, E. M., \& Boaretto, C. (2015). Critical-point model to estimate yield loss caused by Asian soybean rust. Summa Phytopathologica, 41(4), 262-269. https://doi.org/10.1590/0100-5405/2003

EMBRAPA (Empresa Brasileira de Pesquisa Agropecuária). (2010). Tecnologias de produção de soja região central do Brasil 2011. Londrina: Embrapa Soja, Embrapa Cerrados, Embrapa Agropecuária Oeste.

EMBRAPA (Empresa Brasileira de Pesquisa Agropecuária). (2020). Climas. Retrieved September 10, 2020, from http://www.cnpf.embrapa.br/pesquisa/efb/clima.htm

FAO (Food and Agriculture Organization). (1986). Crop yield response to water. Irrigation and Drainage Paper 33 (pp. 15-117).

Farias, J. R. B., Nepomuceno, A. L., \& Neumaier, N. (2007). Ecofisiologia da soja (Circular Técnica 48). Londrina, PR.

Godoy, C. V., \& Canteri, M. G. (2004). Efeitos protetor, curativo e erradicante de fungicidas no controle da ferrugem da soja causada por Phakopsora pachyrhizi, em casa-de-vegetação. Fitopatologia Brasileira, 29, 97-101. https://doi.org/10.1590/S0100-41582004000100016

Godoy, C. V., \& Flausino, A. M. (2004). Efeito da temperatura na germinação de uredosporos de Phakopsora pachyrhizi, viabilidade e sobrevivência em diferentes condições de armazenamento. Fitopatologia Brasileira, 29, 124. https://doi.org/10.1590/S0100-41582004000100016

Guerra, W. D., Machado, A. Q., Cassetari Neto, D., Amaral, S. S., Oliveira, A. S., Block, R., ... Monteiro, B. C. (2010). Viabilidade infectiva de Phakopsora pachyrhizi em soja voluntária no inverno de 2009 no estado de Mato Grosso. 43 Congresso Brasileiro de Fitopatologia, Cuiabá. Tropical Plant Pathology (Vol. 35, p. 129). Lavras: UFLA.

Haas, H. J., Willis, W. O., \& Bond, J. J. (1974). Summer fallow in the western United States (USDA-ARS Conserv. Res. Rep. No. 17). U.S. Gov. Print. Office, Washington, DC.

Hartman, G. L., Rupe, J. C., Sikora, E. J., Domier, J. A., Davis, J. A., \& Steffey, K. L. (2015). Compendium of soybean diseases and pests (5th ed.). The American Phytopathological Society, St. Paul, Minnesota, USA.

IMEA (Instituto Mato-grossense de Economia Agropecuária). (2020a). Indicador Soja. Retrieved from http://www.imea.com.br/imea-site/indicador-soja

INDEA (Instituto Mato-grossense de Defesa da Agropecuária). (2021). Intrução Normativa Conjunta SEDEC/INDEA $n^{o}$ 001/2021. Retrieved from http://www.indea.mt.gov.br

INMET (Instituto Nacional de Meteorologia). (2019). Retrieved July 22, 2019, from http://www.inmet. gov.br/portal

Isard, S. A., Dufault, N. S., Miles, M. R., Hartman, G. L., Russo, J. M., De Wolf, E. D., \& Morel, W. (2006). The effect of solar irradiance on the mortality of Phakopsora pachyrhizi urediniospores. Plant Disease, 90, 941-945. https://doi.org/10.1094/PD-90-0941

Isard, S. A., Gage, S. H., Comtois, P., \& Russo, J. M. (2005). Principles of the atmospheric pathway for invasive species applied to soybean rust. Bioscience, 55, 851-862. https://doi.org/10.1641/0006-3568(2005)055 [0851:POTAPF]2.0.CO;2

Jaccoud-Filho, D., Passini, F. B., Dabul, A. N. G., Granado, C. J. F., \& Figueiredo, M. B. (2007). Alternatives hosts of the agent of the Asian soybean rust (Phakopsora pachyrhizi) in Brazil. Fitopatologia Brasileira, 32, 60-63. 
Marchetti, M. A., Melching, J. S., \& Bromfield, K. R. (1976). The effects of temperature and dew period on germination and infection by uredospores of Phakopsora pachyrhizi. Phytopathology, 66, 461-463. https://doi.org/10.1094/Phyto-66-461

Maude, R. B. (1996). Seedborne diseases and the control principles and practice (pp. 70-88). Oxon: CAB International.

Melching, J. S., Dowler, W. M., Koogle, D. L., \& Royer, M. H. (1989). Effects of duration, frequency, and temperature of leaf wetness periods on soybean rust. Plant Disease, 73(2), 17-122. https://doi.org/ 10.1094/PD-73-0117

Morel, W. (2001). Roya de la soja. Comunicado técnico-Reporte oficial (Serie Fitopatológica $\mathrm{n}^{\mathrm{0}} 1$ - Junho de 2001). Ministerio de Agricultura y Ganaderia, Subsecretaria de Agricultura, Dirección de Investigación Agrícola, Centro de Investigación Agrícola (CRIA), Capitán Miranda, Itapúa, Paraguay.

Nicolini, F., Reis, E. M., Zoldan, S. M., Danelli, A. D., Zanatta, M., Avozani, A., \& Garces, F. R. (2010). Effect of solar irradiation on the Phakopsora pachyrhizi uredospores germination. XLIII Congresso Brasileiro de Fitopatologia, 2010, Cuiabá. Tropical Plant Pathology, 35, S143.

Nutter, F. W., Teng, S. P., \& Royer, M. H. (1993). Terms and concepts for yield, crop, and disease threshold. Plant Disease, 77, 211-215.

Patil, V. S., Wuike, R. V., Chirame, B. B., \& Thakare, C. S. (1998). Viability and survival of uredospores of Phakopsora pachyrhizi Syd in plant debris under different storage conditions. Journal of Soils and Crops, 8 , 16-19.

Pitelli, R. A. (2015). O termo planta-daninha. Planta Daninha, 33(3). https://doi.org/10.1590/S0100-83582015 000300025

Reis, E. M. (2019). Sobre os hospedeiros de Phakopsora pachyrhizi, no Brasil. Summa Phytopathologica, 45(1), 113. https://doi.org/10.1590/0100-5405/177523

Reis, E. M., \& Wordell, J. A. F. (2004). Princípios de epidemiologia. In E. M. Reis (Ed.), Previsão de doenças de plantas (pp. 47-64). Universidade de Passo Fundo, Brazil.

Reis, E. M., \& Zanatta, T. (2016). Curative and erradicant action of fungicides to control Phakopsora pachyrhizi in soybean plants. Summa Phytopathologica, 42(4), 295-302. https://doi.org/10.1590/0100-5405/2180

Reis, E. M., Belufi, L. M. R., Guerra, W. D., Zambolim L., \& Zanatta, M. (2020b). Asian soybean rust severity sowed in different seasons. Journal of Agricultural Science, 12(10), 240. https://doi.org/10.5539/ jas.v12n10p240

Reis, E. M., Casa, R. T., \& Michel, C. (2002). Ocorrência de epidemia da ferrugem da soja no Rio Grande do Sul na safra 2001/2002. Fitopatologia Brasileira, 27, 198-199.

Reis, E. M., Pasquali, R. M., Belufi, L. M. R., \& Guerra, W. D. (2020a). Comparative severity analysis of Asian soybean rust in soybean farms sown in December and February in Mato Grosso, 2018/19 growing season. Journal of Agricultural Science, 12(9), 130. https://doi.org/10.5539/jas.v12n9p130

Reis, E. M., Reis, A. C., \& Zanatta, M. (2018). Reflexo econômico e desenvolvimento da resistência de Phakopsora pachyrhizi a fungicidas em função do número de aplicações. Summa Phytopathologica, 44(3), 289-292. https://doi.org/10.1590/0100-5405/176382

Reis, E. M., Reis, A. C., Zanatta, M., Silva, L. H. C. P., Siqueri, F. V., \& Silva, J. R. C. (2017). Evolução da redução da sensibilidade de Phakopsora pachyrhizi a fungicidas e estratégia para recuperar a eficiência do controle (2nd ed., p. 103). Berthier: Passo Fundo.

Rogers, J., \& Redding, J. (2004). USDA confirms soybean rust in United States. USDA APHIS News, Release No. 0498.04. Retrieved November 11, 2004, from http://www.usda.gov/wps/portal/usadahome

Rossi, R. (2003). First report of Phakopsora pachyrhizi the causal organism of soybean rust in the province of Misiones, Argentina. Plant Disease, 87, 102. https://doi.org/10.1094/PDIS.2003.87.1.102A

Seixas, C. D. S., \& Godoy, C. V. (2007). Vazio sanitário: Panorama nacional e medidas de monitoramento (Embrapa Soja, No. 281 p. 131). Simpósio Brasileiro de Ferrugem Asiática da Soja, Londrina, PR.

Slaminko, T. L., Miles, M. R., Marois, J. J., Wright, L., \& Hartman, G. L. (2008). Hosts of Phakopsora pachyrhizi identified in field evaluations in Florida. Plant Health Progress, 9(1), 6. https://doi.org/10.1094/ PHP-2008-1103-01-RS 
Sousa, P. F. C., Alves, E., \& Castro, H. A. (2006). Influência da temperatura no desenvolvimento de teliósporos de Phakopsora pachyrhizi em folíolos de soja. Summa Phytopathologica, 32(3), 227-231. https://doi.org/ 10.1590/S0100-54052006000300003

Souza, A. P., Zamadei, T., Monteiro, E. B., \& Casavecchia, B. H. (2016). Transmissibilidade atmosférica da radiação global na região Amazônica de Mato Grosso. Revista Brasileira de Meteorologia, 31, 639-648. https://doi.org/10.1590/0102-7786312314b20150147

Sydow, H., \& Sydow, P. (1914). A contribution to knowledge of parasitic fungi of the island of Formosa. Annales Mycologici, 12, 108.

Twizeyimana, M., \& Hartman, G. L. (2010). Culturing Phakopsora pachyrhizi on detached leaves and urediniospore survival at different temperatures and relative humidities. Plant Disease, 94, 1453-1460. https://doi.org/10.1094/PDIS-02-10-0131

\section{Copyrights}

Copyright for this article is retained by the author(s), with first publication rights granted to the journal.

This is an open-access article distributed under the terms and conditions of the Creative Commons Attribution license (http://creativecommons.org/licenses/by/4.0/). 